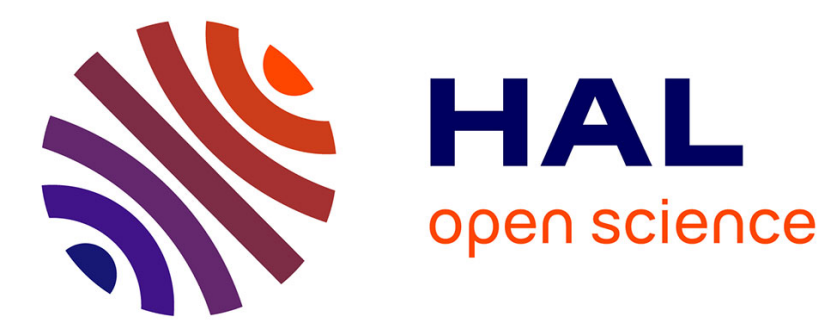

\title{
Bringing It All Back Home: Return migration and fertility choices
}

\author{
Simone Bertoli, Francesca Marchetta
}

\section{To cite this version:}

Simone Bertoli, Francesca Marchetta. Bringing It All Back Home: Return migration and fertility choices. World Development, 2015, 65, pp.27-40. 10.1016/j.worlddev.2013.08.006 . hal-03260964

\section{HAL Id: hal-03260964 https://hal.uca.fr/hal-03260964}

Submitted on 15 Jun 2021

HAL is a multi-disciplinary open access archive for the deposit and dissemination of scientific research documents, whether they are published or not. The documents may come from teaching and research institutions in France or abroad, or from public or private research centers.
L'archive ouverte pluridisciplinaire HAL, est destinée au dépôt et à la diffusion de documents scientifiques de niveau recherche, publiés ou non, émanant des établissements d'enseignement et de recherche français ou étrangers, des laboratoires publics ou privés. 


\title{
Bringing It All Back Home Return migration and fertility choices
}

\author{
Simone Bertoli ${ }^{a}$ and Francesca Marchetta ${ }^{b}$ \\ ${ }^{\mathrm{a}} C E R D I^{*}$, University of Auvergne and CNRS \\ ${ }^{\mathrm{b}} \mathrm{CERDI} I^{\dagger}$, University of Auvergne
}

\begin{abstract}
Return migration exerts a wide-ranging influence upon the countries of origin of the migrants. We analyze whether returnees adjust their fertility choices to the norms that prevail in their previous countries of destination using Egyptian household-level data. Egyptian men migrate predominantly toward other Arab countries characterized by a higher number of children per woman. Relying on a two-step instrumental variable approach to control for the endogeneity of the migration decisions, we show that return migration has a positive and significant influence on marital childbearing.
\end{abstract}

Keywords: temporary migration; fertility; household-level data; North Africa; Egypt.

JEL codes: F22; J13; O12.

${ }^{*}$ Centre d'Études et de Recherches sur le Développement International, University of Auvergne, Bd. F. Mitterrand, 65, F63000, Clermont-Ferrand; email: simone.bertoli@udamail.fr (corresponding author).

†email: francesca.marchetta@udamail.fr. 


\section{Introduction}

"Millions of Egyptians flocked to work in the Gulf, and came back years later with money and Wahhabi ideas [...] In reality the Wahhabi ideology sees women as merely vessels for sex, a source of temptation, and a means to produce children."

Alaa Al Aswany (2011), On the State of Egypt

The relevance of international migration goes well beyond the sheer physical movement of people, as migration also represents a powerful mechanism to transmit ideas across borders. Spilimbergo (2009) shows that student migration toward democratic countries promotes democracy at home, while Batista and Vicente (2011) and Docquier et al. (2011) demonstrate that migration can improve the quality of domestic institutions, with the strength of such an effect being increasing with the level of education of the migrants and dependent on their sorting across destinations (Beine and Sekkat, 2012). Lodigiani and Salomone (2012) provide evidence that international migration increases female parliamentary representation at home when it is directed toward countries with a higher female political empowerment. Return migrants can bring back home a stronger entrepreneurial attitude (Piracha and Vadean, 2010; Wahba and Zenou, 2012), which helps their activities to survive over time (Marchetta, 2012).

International migration can also influence fertility decisions at origin as it changes the economic incentives that the parents face (Chen, 2006; Marchiori et al., 2010; Mountford and Rapoport, 2011) and as it exposes them to the fertility norms that prevail at destination (Fargues, 2007, 2011a; Beine et al., 2012). Specifically, Fargues (2007, 2011a) suggested that fertility at origin can be endogenous to migration, as migrants enter in contact with the social determinants of fertility, such as female access to education and to the labor market, that prevail at destination and they transfer the ensuing fertility norms back home. Beine et al. (2012) describe the various channels through which migration could influence 
fertility at origin and provide econometric evidence of the migration-induced transfer of fertility norms using aggregate data and tackling the endogeneity of the sorting of migrants across destinations, which influences the norms they are exposed to. ${ }^{1}$ Their results imply that migration toward high-income OECD countries can contribute to narrow down the demographic imbalances between the countries of origin and destination, ${ }^{2}$ while migration toward high-fertility countries, such as the Arab countries in the Gulf, can slow down the pace of demographic transition at origin. ${ }^{3}$

Migration toward the high-income Arab countries is almost exclusively male and predominantly temporary in nature, ${ }^{4}$ and hence one can reasonably expect that returnees would be the primary and direct channel of transmission of the fertility norms that prevail at destination. The objective of this paper is to understand whether the married couples where the husband is a returnee from a high-fertility destination country have a larger number of children than the couples of stayers. Specifically, we test whether a temporary migration experience in an Arab country exerts a significant influence on the fertility choices of Egyptian households. As recalled in the initial quote from Al Aswany (2011), Egypt has been experiencing massive waves of migration toward oil-producing Arab countries since the early 1970s, and we are going to use household-level data to explore the relationship between the past migration experience and fertility decisions.

We estimate a Poisson regression where the dependent variable is represented by the total number of live births recorded by a couple at the time of the 2006 Egyptian Labor Market Panel Survey, ELMPS, which represents our main source of data. A key analytical challenge is represented by the non-random selection of Egyptian migrants with respect to unobservable characteristics that can also have an impact on their fertility decisions. Egyptian male migrants to Arab countries might be open-minded individuals with loose family ties, or they might have conservative attitudes that resonate well with the social and cultural values that prevail at destination. We tackle the threat to identification posed by 
the endogeneity of the decision to migrate following Wahba and Zenou (2012) and Marchetta (2012) who rely on the fluctuations in the real price of oil to obtain an exogenous source of variation in the probability to migrate. The use of this instrument opens up the question of the age at which each male individual in our sample has to be matched to the corresponding real price of oil, and we rely on an explicit optimality criterion to chose among the alternative options. As our equation of interest is non linear, we implement our instrumental variable strategy using the two-stage residual inclusion, 2SRI, estimator proposed by Terza et al. (2008).

This two-step approach allows us to remove the bias due to the non-random selection into migration, but it does not allow us to isolate the transfer of fertility norms that influence preferences toward the desired number of children. What we estimate is the aggregate effect of the migration experience, which might also capture an income effect upon the desired or actual family size that goes through the savings accumulated abroad and the impact of migration experience on earning opportunities in Egypt. While we do not have data on foreign savings, we can control for the economic conditions of the household through an index computed following Filmer and Pritchett (2001) that aggregates information on asset holdings measured after the end of the migration experience, and that thus reflects the accumulation of foreign savings. We can also observe that return migration could exert an influence that goes beyond its direct effect that we estimate: returnees could play a catalytic role, ${ }^{5}$ spreading changing attitudes toward fertility also to stayers. If return migration also has a diffuse influence upon other Egyptians, then the comparison of returnees with stayers in the econometric analysis would provide us with a lower bound of its actual direct impact upon returnee households.

The estimates reveal that Egyptian couples where the husband is a returnee from an Arab country have a significantly larger number of children. The result is actually stronger once we control for the endogeneity of the migration decision through the adoption of the 
2SRI estimator. The real price of oil enters positively and significantly in the first stage equation, and the generalized residuals that we compute from this auxiliary regression have a negative and significant impact on the total number of children. This confirms that migration experience is endogenous, and it reveals that returnees have on average unobservable characteristics that are associated with a lower level of fertility.

The paper is structured as follows: Section 2 discusses the arguments about the direct influence of migration upon the fertility choices of Egyptian returnees, and Section 3 presents the econometric approach that we use to identify the impact of return migration on fertility decisions. Section 4 describes the sources of the data, and it presents the relevant descriptive statistics. The estimates and the robustness checks are presented in Section 5, while Section 6 draws the main conclusions of the paper.

\section{Return migration and fertility in Egypt}

The direct influence of temporary migration experiences on the reproductive choices of the returnees depends on the relative timing of the decisions concerning migration and marriage, ${ }^{6}$ and it can be magnified when the former precedes the latter as this increases returnees' responsiveness to the norms that they observed while abroad. This appears to be the case for Egypt, a country that has experienced a substantial increase in the age at marriage (Fargues, 2011b), and where having migrated abroad significantly increases the hazard of getting married (Assaad et al., 2010).

Egyptians directed toward other Arab countries enter in contact with different norms concerning fertility, which can be at least partly related to significant differences in the religious attitudes toward childbearing that prevail in Muslim countries, as McQuillan (2004) observes that "what is striking in the case of Islam [...] is the variability in its message on key demographic questions" (p. 42). While the Islamic influence is usually related to the 
persistence of a high number of children per woman in Saudi Arabia (McQuillan, 2004), we can notice that the Grand Mufti of Egypt had released a fatwa that approved the use of birth control techniques already in 1937 (Omran, 1992). ${ }^{7}$

The influence of religion on fertility choices goes beyond its specific teachings on childbearing and it actually goes through the prescriptions related to "the total content of $[\ldots]$ social organization" (Goldscheider, 1971, p. 274), including gender roles. Clingingsmith et al. (2009) provide experimental evidence of how "experiential knowledge of the diversity of Islamic practices and beliefs, [and] gender roles within Islam" (p. 1137) during the Hajj influences pilgrims' attitudes toward women. This suggests that temporary migration experiences in other Muslim countries can have an influence on the preferences of the returnees concerning their desired family size or the social determinants of fertility, ${ }^{8}$ such as female participation in the labor market. ${ }^{9}$ The econometric analysis of the impact of temporary male migration on the labor market participation of Egyptian women by Binzel and Assaad (2011) reveals a decline in wage work and an increase in subsistence work and employment in family-run activities, a pattern that might be detrimental for the status of the women within their households.

Even though only Egyptian men enter into direct contact with the fertility norms that prevail at destination and a change in their desired number of children might produce no influence on the preferences held by their wives (Cochrane et al., 1990), ${ }^{10}$ the total number of children would still respond to this change as far as fertility choices are the outcome of a bargaining between the two spouses (Lehrer, 1996; Rasul, 2008). The contact with norms that favor a higher number of children should then positively influence the total number of children of the couples where the man is a returnee. Temporary migration toward other Arab countries could also increase the total number of children if it induces stronger "preference for sons", with couples targeting a desired number of male offsprings (Ray, 1998). ${ }^{11}$

The impact of a temporary migration experience upon the returnees' choices concerning 
fertility does not only go through the contact with different norms, but it can also be influenced by the income effect due to migration. Specifically, the savings accumulated abroad can influence desired fertility in opposite directions. If parents regard children as normal goods, then the positive wealth effect due to migration would increase their demand for children, but the same wealth effect would also depress the demand for children that is motivated by old-age security concerns (Nugent, 1985). ${ }^{12}$ Furthermore, the savings accumulated by Egyptian returnees can be used to set up entrepreneurial activities (McCormick and Wahba, 2001; Wahba and Zenou, 2012) that have better chances to survive over time (Marchetta, 2012). This can induce a negative substitution effect on the demand for children as it raises their opportunity costs through expanded opportunities for female employment. ${ }^{13}$ These ambiguous impacts of the income effects produced by migration calls for controlling for household economic conditions when estimating the influence exerted by a past migration experience in an Arab country on fertility among returnees.

\section{Empirical strategy}

Let $q_{i}$ denote the number of children of woman $i$; if $q_{i}$ follows a univariate Poisson process, then:

$$
\operatorname{Pr}\left(q_{i}=y\right)=\frac{e^{-\mu_{i}} \mu_{i}^{y}}{y !}, \text { with } y \in \mathbb{N}_{0}
$$

where the parameter $\mu_{i}$ in (1) represents the mean and the variance of $q_{i}$ that we assume to be an exponential function of a vector $\boldsymbol{x}_{i}$ of covariates describing the relevant characteristics of the couple, ${ }^{14}$ that is:

$$
\mu_{i}=e^{\boldsymbol{x}_{i}{ }^{\prime} \boldsymbol{\beta}+u_{i}}
$$


The error term $u_{i}$ in (2) follows:

$$
u_{i}=\rho \epsilon_{i}+\nu_{i} .
$$

The vector of covariates $\boldsymbol{x}_{i}=\left(y_{2 i}, \boldsymbol{x}_{1 i}{ }^{\prime}\right)^{\prime}$ in (2) includes a sub-vector $\boldsymbol{x}_{1 i}$ whose elements are uncorrelated with (3), and one regressor $y_{2 i}$ that is orthogonal to $\nu_{i}$ but correlated with $\epsilon_{i}$. The estimation of the determinants of the number of children $q_{i}$ delivers a consistent estimate of the vector of coefficients $\boldsymbol{\beta}$ only if $\rho=0$, as this condition entails the exogeneity of $y_{2 i}$, while $y_{2 i}$ is endogenous whenever $\rho \neq 0$.

In our case, $y_{2 i}$ is a dichotomous variable that is equal to one if the husband of woman $i$ is a returnee from an Arab country. If Egyptian migrants are not randomly selected in unobservables that also influence the fertility choices of the couple, we need to tackle the threat to identification posed by the endogeneity of migration in the fertility equation. Let:

$$
\operatorname{Pr}\left(y_{2 i}=1 \mid \boldsymbol{x}_{1 i}, \boldsymbol{x}_{2 i}\right)=\Phi\left(\boldsymbol{x}_{1 i}{ }^{\prime} \boldsymbol{\gamma}_{\mathbf{1}}+\boldsymbol{x}_{2 i}{ }^{\prime} \boldsymbol{\gamma}_{\mathbf{2}}\right)
$$

where the vector $\boldsymbol{x}_{2 i}$ is excluded from (2), and $\Phi($.$) represents the cumulative density$ function of the standard normal distribution. The generalized residuals (Gourieroux et al., 1987) from (4) are given by:

$$
\widetilde{e}_{i}(\widehat{\gamma})=\phi\left(\boldsymbol{x}_{1 i}{ }^{\prime} \widehat{\gamma}_{1}+\boldsymbol{x}_{2 i}{ }^{\prime} \widehat{\gamma}_{2}\right) \frac{y_{2 i}-\Phi\left(\boldsymbol{x}_{1 i}{ }^{\prime} \widehat{\gamma}_{1}+\boldsymbol{x}_{2 i}{ }^{\prime} \widehat{\gamma}_{2}\right)}{\Phi\left(\boldsymbol{x}_{1 i}{ }^{\prime} \widehat{\gamma}_{1}+\boldsymbol{x}_{2 i}{ }^{\prime} \widehat{\gamma}_{2}\right)\left[1-\Phi\left(\boldsymbol{x}_{1 i}{ }^{\prime} \widehat{\gamma}_{1}+\boldsymbol{x}_{2 i}{ }^{\prime} \widehat{\gamma}_{2}\right)\right]}
$$

where $\phi($.$) represents the probability density function of the standard normal distribution,$ and $\widehat{\gamma}=\left(\widehat{\gamma}_{1}^{\prime}, \widehat{\gamma}_{2}^{\prime}\right)^{\prime} \cdot{ }^{15}$ Terza et al. (2008) demonstrate that a consistent estimate of the vector of coefficients $\boldsymbol{\beta}$ can be obtained by replacing the unobserved $\epsilon_{i}$ with the generalized residual $\widetilde{e}_{i}(\widehat{\gamma})$, while keeping the observed value of the endogenous covariate $y_{2 i}$ in the vector of regressors. ${ }^{16}$ The non-linearity of the second stage equation implies the inconsistency of 
the estimates of $\boldsymbol{\beta}_{1}$ and $\beta_{2}$ obtained with the two-stage predictor substitution estimator, which would require estimating (4) and then replacing the endogenous regressor $y_{2 i}$ with its predicted value $\widehat{y}_{2 i}$ (Terza et al., 2008).

The Poisson equation to be estimated through maximum likelihood thus becomes:

$$
\mu_{i}=e^{\boldsymbol{x}_{1 i}{ }^{\prime} \boldsymbol{\beta}_{1}+\beta_{2} y_{2 i}+\rho \widetilde{e}_{i}(\widehat{\gamma})+\nu_{i}}
$$

The estimate of $\boldsymbol{\beta}$ obtained through maximum likelihood retains its consistency even if the data are not Poisson-distributed, provided that the conditional mean $\mu_{i}$ in $(6)$ is correctly specified (Gourieroux et al., 1984). The relaxation of the distributional assumptions on the error term requires to estimate the standard errors in a way that is robust to the violation of the equidispersion property of the Poisson distribution. Whenever the estimated coefficient $\widehat{\rho}$ is significantly different from zero, one has to resort to bootstrapping to account for the additional variability that is introduced in (6) by the estimation of the generalized residuals $\widetilde{e}_{i}(\widehat{\gamma})$.

\section{The data}

Our data come from the 2006 wave of the Egyptian Labour Market Panel Survey undertaken by the Central Agency for Public Mobilization and Statistics, CAPMAS, and by the Economic Research Forum. This nationally representative survey provides indirect information on the international migration experiences of the household members and it also contains a complete record of the offspring of ever-married women aged 16 to $49 .{ }^{17}$ The ELMPS 2006 allows us to identify as returnees the individuals who report to have been residing or working abroad before the survey. Specifically, the survey contains questions about the two previous places of residence and about the locations of the previous two jobs held by the respondents, 
while it does not contain any specific question on past migration experiences. This entails that we can identify as a returnee all individuals who report a foreign country in the answer to any of these four questions. Such an identification of the returnees is possibly subject to some measurement error, as we classify as a stayer a returnee who changed residence and job more than twice after his last return to Egypt. The ELMPS 2006 also provides data on the year in which each interviewee started their previous two jobs; for returnees, this variable can provide us with an upper bound of the age at the time of migration.

Our sample includes married couples where the women are aged 16 to 49, and we exclude those women whose spouses $(i)$ are currently absent from the household or $(i i)$ migrated to a non-Arab country in the past. These two sample selection criteria allow us to focus on Egyptian returnees from Arab countries only, ${ }^{18}$ and to compare them with the sample of never-migrant households. The resulting sample includes 5,732 married couples, with 394 of them, corresponding to 7.5 percent of the population of reference, including a husband who has migrated to an Arab country in the past. ${ }^{19}$

The ELMPS 2006 does not provide accurate information on the age at migration; the proxy represented by the year in which a returnee took up a job position abroad, which is non-missing for 334 out of the 394 returnees in our sample, has a median that stands at 24 years; this represents an overestimate of the age at migration if the survey fails to record the first job held abroad. ${ }^{20}$

The Arab countries of destination of Egyptian returnees that are recorded in the ELMPS 2006 are Algeria, Iraq, Jordan, Kuwait, Lebanon, Libya, Oman, Qatar, Saudi Arabia, Syria, United Arab Emirates and Yemen, with Saudi Arabia representing the most relevant migrant destination, as evidenced in Table 1. According to the matrix of bilateral migrant stocks presented in Ozden et al. (2011), the 12 countries of destination included in Table 1 hosted 79.0 percent of the Egyptians residing abroad in $2000,{ }^{21}$ though this figure probably understates the relevance of these destinations given the predominant temporary character 
of Egyptian migration toward these countries (World Bank, 2009).

Table 2 reports the total fertility rates that prevailed in Egypt and in the 12 countries of destination included in Table 1 between 1970 and the end of the 1990s. The total fertility rate in Egypt declined from 5.77 to 3.52, and it was always between 1.04 and 1.55 children per woman lower than the average for the countries of destination. While Lebanon was the only destination country with a total fertility rate below the corresponding Egyptian figure at the beginning of the 1970s, six destinations had a lower number of children per woman thirty years later. ${ }^{22}$

Table 3 presents some key descriptive statistics. The couples where the husband is a returnee from an Arab country have on average 3.24 children, while stayers have on average 2.57 children. ${ }^{23}$ The data also reveal, in line with the evidence provided by Basu and Jong (2010), the presence of the sibling and the birth-order effect that are induced by the adoption of a male-preferring stopping rule. Specifically, the female children of the couples in our sample have 0.08 more siblings than male offsprings, and they are born at a lower parity. ${ }^{24}$

The difference in the number of children is substantial, and it probably reflects some relevant differences between the two groups with respect to observable characteristics: the duration of the wedding for returnees stands at 15.64 years, above the corresponding figure for stayers that stands at $11.87 .^{25}$ For both groups, husbands are significantly older then their wives: male stayers are nearly seven years older than their spouses, while the age differential in returnee couples exceeds eight years. Wives in both groups have around 6.7 years of completed schooling, while male returnees have 6.8 years of completed schooling, below the 7.3 years recorded for stayers. The couples of returnees enjoy a better socioeconomic condition, as measured by an asset index that we computed following Filmer and Pritchett (2001) with a principal component analysis applied to a vector of 19 variables, measured at the time of the survey, which describe the characteristics of the dwelling and the ownership of some consumer durables. ${ }^{26}$ 
Table 3 also reports the level of education and the number of children of the mothers of the wives included in our sample, which are consistent both with the improvement in the level of education and with the decline in fertility levels in Egypt over the past few decades. While, as recalled above, the married women aged 16 to 49 who form our sample have on average 6.7 years of completed schooling, 79 percent of their mother were illiterate. They had, on average, 6.49 children, well above the 2.63 recorded for their daughters, though this difference is also affected by the fact that most the women in the latter group were still fertile at the time of the survey.

Table 3 also reveals that when returnees were 20 years old, ${ }^{27}$ they faced a real oil price equal to $\$ 49.84$, while the corresponding figure for stayers stands at $\$ 39.41$. This is consistent with the idea that the decision to migrate toward an Arab country is influenced by labor market conditions at destination, which are in turn deeply shaped by the ups and downs in the price of oil.

Figure 1 plots the evolution of the share of male returnees by year of birth between 1950 and 1986, together with the real price of oil measured at the age of $20 .{ }^{28}$ Figure 1 shows that the share of returnees is highest, close to 20 percent, for the Egyptians born at the end of the 1950s, who probably migrated to other Arab countries in correspondence with the second oil crisis at the end of the 1970s and early 1980s. After this peak, the share of returnees fell, together with the steady decline of the real price of oil up to the end of the 1990s. The comparison of the two series for the males born after 1980 signals a surge in the real price of oil, with no corresponding increase in the share of returnees, as Egyptian migrants who left in the early 2000s had probably not yet completed their migration experience at the time of the survey.

The ELMPS 2006 also provides a limited set of information about the household members who were abroad at the time of the survey ${ }^{29} 502$ individuals were reported to be residing in an Arab country included in Table 1, and 350 of them had left Egypt after 2000, suggesting 
that the surge in the oil price in the early 2000s was also matched by a sustained migration wave. Interestingly, the survey contains a question on the year in which these migrants visited their household for the last time: 64.3 percent of them had returned home at least once for less than six months in the two years before the survey, and this implies that married Egyptians who moved to an Arab country have some opportunities for sexual intercourse with their spouses also during their migration experiences.

The survey presents some features that represent a limitation for our analysis. Specifically, it provides no data on the extended family of the respondents, unless they belong to the same household, and this prevents us from controlling for the possible influence of the migration experiences of other relatives on the fertility decisions of the married couples in our sample.

\section{$5 \quad$ Econometric analysis}

The dependent variable $q_{i}$ is represented by the cumulative fertility, i.e. the total number of live births at the time of the survey, of each married woman in our sample. The vector of regressors $\boldsymbol{x}_{1 i}$ that is expected to influence the number of children $q_{i}$ of woman $i$ in our sample includes $(i)$ an index of household $\operatorname{assets}^{30}$ and the duration of the wedding, $(i i)$ characteristics of the wife, (iii) characteristics of her mother ${ }^{31}$ and $(i v)$ characteristics of the husband. Specifically, with respect to $(i i)$ we include the number of completed years of schooling and the age at the time of the wedding, ${ }^{32}$ while for ( $\left.i i i\right)$ we control for the level of education of the mother and for the number of children that she had. ${ }^{33}$ With respect to the husband, beyond the migration experience, we control for the completed number of years of schooling. ${ }^{34}$ Furthermore, we also control for the distance to the nearest health clinic, which represents a proxy for the access to family planning and birth control techniques, and we include dummies for each one of the Egyptian governorates covered by the survey, which 
remove from the estimates the influence of spatial differences in the incidence of migration that correlate with preferences toward the number of children. We opted for a parsimonious specification of $\boldsymbol{x}_{1 i}$ to reduce, though possibly not to eliminate completely, the concerns connected to the possible endogeneity of its elements. We provide evidence below that this selection of regressors suffices to reach a good fit of the observed fertility choices in our sample, measured, as suggested by Cameron and Trivedi (2010), by the correlation between the actual and the predicted values of the dependent variable.

\subsection{Selection of the instrument}

Beyond the controls included in the vector $\boldsymbol{x}_{1 i}$, the key variable of interest is represented by $y_{2 i}$, which describes the past migration experience of the husband in an Arab country.

Following Wahba and Zenou (2012) and Marchetta (2012), we rely on the real price of oil to obtain an exogenous source of variation in $y_{2 i}$. This variable can have a substantial influence on the scale of migration toward oil-producing countries that adopt employerdriven immigration systems that respond to fluctuations in local economic conditions. ${ }^{35}$ Furthermore, as Egyptian migration toward Arab countries is almost exclusively temporary in nature, ${ }^{36}$ a variable that predicts the beginning of the migration experience is also a suitable instrument for return migration.

Our instrument would be invalid if the fluctuations of the real oil price influenced female participation on the labor market, thus modifying a key proximate determinant of fertility. Specifically, Egypt is also an oil-producing country, and an increase in oil rents could give rise to heterogeneous effects across sectors, with an expansion of non-traded and a contraction of tradable sectors. As the demand for female labor in Egypt originates predominantly from tradable sectors (Assaad, 2004), then the fluctuations in the real oil price could influence female participation on the labor market (Ross, 2008). We discuss at the end of this section 
why this argument does not lead to a violation of the exclusion restriction.

An alternative time-varying instrument could have been represented by the data on the yearly inflows of Filipino migrants collected by the Philippine Overseas Employment Administration. These data offer an exogenous measure of the destination-specific demand for immigrant labor that we might have been used to exploit differences in fertility norms across Arab countries, ${ }^{37}$ but unfortunately the data are available only since 1992, thus lacking the longitudinal dimension that is needed for our analysis.

The use of the real price of oil as an instrument for migration experience requires selecting the age at which each male individual in the sample is associated to the corresponding real oil price. We adopted the following criterion to guide our choice: we estimated the auxiliary regression that is used to generate the generalized residuals $\widetilde{e}_{i}(\widehat{\gamma})$ using as an instrument $x_{2 i s}$, which is the real price of oil measured when the individual $i$ in our sample was $s$ years old, for $s=18, \ldots, 28 .{ }^{38}$ Then, for each specification, we tested the null hypothesis that the estimated coefficient of $x_{2 i s}$ is equal to zero through a $\chi^{2}(1)$ test, and we selected the age $s$ that produced the highest value of the test statistics. Figure 2 reports the test statistics for each of the specification of the auxiliary regression, together with the 1 percent critical value of the $\chi^{2}(1)$ distribution.

The value of the test statistics is highest when $s$ is equal to 20, and it falls below the 1 percent critical value for $s \geq 26$. Hence, we selected as our instrument $x_{2 i}$ the real oil price measured when the husband was 20 years old. Wahba and Zenou (2012) opt for the real price of oil at the age of 28 years,${ }^{39}$ with Figure 2 revealing that this would be a highly suboptimal choice on our sample and given the specification of the auxiliary regression. The choice of our instrument entails that we restrict our sample to the couples for which we have information on the real price of oil in the year in which the husband was 20 years old.

The use of the real oil price measured at the age of 20 is consistent with the fact that the median of our proxy for the age at migration stands at 24 years. Returnees might have been 
engaged in multiple migration episodes, ${ }^{40}$ and the survey, which records only the location of the previous two jobs, is unlikely to provide us with information on the timing of the first migration episode. This, in turn, might have occurred around the age of 20 , followed by later migration episodes that are recorded by the survey. ${ }^{41}$

With respect to the threat to the validity of the exclusion restriction, we can observe that the age difference between the two spouses plays a key role in mitigating the concern discussed above. Specifically, Table 3 reveals that wives are approximately seven years younger than their husbands; this entails that our instrument is measured well before the beginning of the period of marital fertility, as the women in our sample were, on average, 19.68 years old at the time of the wedding. This would be insufficient to dismiss the concerns related to the validity of the exclusion restriction if there was a strong serial correlation in the evolution of the real oil price, but the data reveal that the correlation between the real oil price in year $t$ and in year $t+7$ stands at 0.097 ; furthermore, the correlation between our instrument and a dummy variable that signals whether each woman in our sample is active on the labor market is low and actually positive. This, in turn, further helps to reduce the concerns about the empirical relevance of a direct relationship between our instrument and fertility choices.

\subsection{Estimation results}

Table 4 presents the benchmark estimates of our fertility regression, which retain their consistency even if the error term is not Poisson-distributed. ${ }^{42}$ Specification (1), which does not include the migration experience of the husband among the regressors, shows that the duration of the wedding exerts, as expected, a positive and highly statistically significant impact on the number of children of the couple. The asset index has a negative and statistically significant coefficient, which is suggestive that better economic conditions induce a negative 
substitution effect on the number of children. ${ }^{43}$ The coefficient of the age of the wife at the time of the wedding is negative, albeit not statistically significant in this specification. Marital fertility is negatively and significantly related to the number of years of schooling of the wife, while the corresponding variable for the husband is not significant. ${ }^{44}$

Cumulative fertility is declining with the level of education of the mother of the wife, ${ }^{45}$ while it is significantly increasing with the number of children of the previous generation. Specification (1) also reveals that the total number of children is increasing with the time that is required to reach the nearest health clinic, and for households who reside in rural areas. The inclusion of governorates dummies ${ }^{46}$ allows us to have a correlation of 0.56 between the actual and the predicted number of children for the couples in our sample.

Specification (2) in Table 4 introduces the migration experience of the husband among the regressors. ${ }^{47}$ The estimated coefficient is positive and highly statistically significant. Still, the threat to identification posed by the possible correlation of this variable with the error term entails that we should not blur correlation with causation.

As discussed in Section 2, we tackle the endogeneity of this regressor through the adoption of the 2SRI estimator: we first estimate the auxiliary probit regression described in (4), where the estimated coefficient $\widehat{\gamma}_{2}$ of the real price of oil at the age of 20 is positive and significant, ${ }^{48}$ and then we compute the generalized residuals $\widetilde{e}_{i}(\widehat{\gamma})$. Specification (3) in Table 4 includes the generalized residuals among the regressors: the estimated coefficient is significant, confirming that the migration experience variable is endogenous, and negative, suggesting that Egyptian migrants to Arab countries are self-selected among the individuals with unobservable characteristics that are associated with a lower level of fertility. The inclusion of the generalized residuals also induces a marked increase in the point estimate of the coefficient of the endogenous migration experience variable, though the analytic standard errors reported in specification (3) cannot be relied upon to assess its significance, as they neglect the variability associated with the estimated auxiliary regressor $\widetilde{e}_{i}(\widehat{\gamma})$. 
Specification (4) provides the estimates of the specification that includes the generalized residuals, reporting the standard errors obtained with bootstrapping. The bootstrapped standard error associated to the estimated coefficient for return migration is larger than the analytic one, but it still allows us to reject at the 5 percent confidence level the null hypothesis that the coefficient is equal to zero. The estimated coefficients for the other regressors are largely unaffected by the adoption of the 2SRI estimator, with the exception of the age of the wife at the wedding that is now significant, suggesting that an early wedding is associated, even controlling for its duration, with a higher number of children.

The estimated coefficient of our variable of interest could be capturing not just the effect due to the transfer of fertility norms but also influence of the wealth effect induced by the past migration experience of the husband if the asset index does not fully control for its influence on marital fertility. In such a case, we might have that the wives of the returnees had a lower rate of participation on the labor market, which reduces the opportunity cost of child rearing. The ELMPS 2006 survey provides us with information about the employment status of the women in our sample, and 21.3 percent of them report to have been employed during the one-week reference period before the survey. Interestingly enough, this figure is substantially higher for the wives of the returnees (33.7 percent) than for the wives of stayers (20.3 percent). The higher employment rate of the wives of the returnees appears to be connected to the occupational choice of their husbands upon return (McCormick and Wahba, 2001; Wahba and Zenou, 2012; Marchetta, 2012), as the employment rate goes up to 42.0 percent for the wives of the returnees who opted for entrepreneurial activities. This, in turn, suggests that the estimated positive coefficient for return migration should not be reflecting the influence of the positive wealth effect due to migration upon marital fertility, although we cannot claim that this just captures the effect due to the transfer of fertility norms.

As in any non-linear model, the effect of a change in any of the regressors depends on 
the values of all the regressors. Using (6), the estimated effect of return migration upon the total number of children of a couple, once we account for its endogeneity, is given by:

$$
\begin{array}{r}
E\left[\mu_{i} \mid y_{2 i}=1, \widehat{\boldsymbol{\beta}}, \widehat{\rho}, \boldsymbol{x}_{1 i}, \widetilde{e}_{i}(\widehat{\gamma})\right]-E\left[\mu_{i} \mid y_{2 i}=0, \widehat{\boldsymbol{\beta}}, \widehat{\rho}, \boldsymbol{x}_{1 i}, \widetilde{e}_{i}(\widehat{\gamma})\right]= \\
\left(e^{\widehat{\beta}_{2}}-1\right) e^{\boldsymbol{x}_{1 i}{ }^{\prime} \widehat{\boldsymbol{\beta}}_{1}+\widehat{\rho} \widetilde{\rho}_{i}(\widehat{\gamma})},
\end{array}
$$

where $\widehat{\boldsymbol{\beta}}=\left(\widehat{\boldsymbol{\beta}}_{1}^{\prime}, \widehat{\boldsymbol{\beta}}_{2}\right)^{\prime}$. Computing (7) for the sub-sample of returnees gives us the average treatment effect on the treated: return migration from an Arab country increases the predicted total number of children by 1.20 children, with a standard error of 0.37 associated to this point estimate. This figure is above the difference in the observed number of children between returnees and stayers, which stands at 0.67 children as evidenced in Table 3, and above the difference 0.24 that can be estimated according to (7) on the basis of specification (2) in Table 4, which controls only for the differences in observables between the two groups. This is consistent with the estimated negative and significant coefficient for the generalized residuals $\widetilde{e}_{i}(\widehat{\gamma})$ : the married couples where the husband is a returnee from an Arab country are endowed with unobservable characteristics that are negatively associated with their total number of children.

Which factors can help us to understand this result and the increase in the estimated coefficient of return migration once we apply the 2SRI estimator? We can advance some conjectures to explain this pattern in the estimates. First, The ELMPS 2006 does not contain direct questions on past migration history, as discussed in Section 3, so that instrumentation might be removing an attenuation bias due to the measurement error in our key variable of interest. A second possible explanation might be related to the laws that regulate conscription: Egyptian men need to have cleared their military service obligations before they can get a passport; males with no brothers and those who are the main breadwinners in their 
families, such as the firstborn child of a widow, are exempted from conscription ${ }^{49}$ and hence can get a passport and migrate out of Egypt. ${ }^{50}$ This suggests that individuals coming from smaller families might be better able to migrate, and the (smaller) size of the family of origin could have an impact on their desired number of children. A third conjecture relates to the fact that Egyptian returnees predominantly originate from larger neighborhoods with less dense social networks (Wahba and Zenou, 2012, p. 898), where married couples might be less exposed to peer pressure related to the adherence to the prevailing fertility norms.

\subsection{Robustness checks}

Figure 1 evidenced that the sharp increase in the real price of oil since the end of the 1990s is not matched by a corresponding increase in the share of returnees. This does not reflect a structural change in the relationship that we relied upon to derive an exogenous source of variation in the probability to migrate, but it is rather related to the fact that the Egyptians who moved to an Arab country in response to this increase in the real price of oil had not yet come back home at the time of the survey, as discussed in Section 4. Specifications (1)-(2) in Table 5 report the estimates obtained when we restrict the sample to the couples where the husband was at least 25 years old at the time of the survey. ${ }^{51}$ The results are virtually unaffected by this restriction.

Our identification strategy is centered around the role of the real price of oil in influencing the size of Egyptian migration. Still, some of the 12 destination countries in our sample such as Jordan, which is the third most relevant destination according to Table 1, are actually not oil producers. ${ }^{52}$ Specifications (3)-(4) in Table 5 restrict the estimation to the sample that includes only stayers and returnees from countries that are members of the Organization of the Petroleum Exporting Countries, OPEC. The estimates obtained both when treating migration status as exogenous and when accounting for its endogeneity with the proposed 
two-step estimation are unchanged by a restriction of the sample that is more coherent with our choice of the instrumental variable.

As discussed in Section 4, the duration of the wedding of the returnees is 3.87 years above the corresponding figure for stayers. The vector of regressors includes this variable among the determinants of marital fertility, but the difference between the two groups could still be confounding the estimated effect of our variable of interest. Specifications (5)-(6) in Table 5 is based on a sample of women aged 27 and above. This allows us to discard the couples where the wife is the early stages of her fertility cycle, as the median and the mean age at childbearing stand at 26.0 and 26.1 years respectively. ${ }^{53}$ The estimated coefficients for return migration in the uninstrumented and in the instrumented specification are smaller than those obtained on the entire sample, but neither of the two differences is significant at conventional confidence levels.

Although Table 2 did not evidence major differences in the level of fertility across the Gulf countries and the other Arab countries of destination of the Egyptian migrants, the initial quote of this paper from Al Aswany (2011) makes an explicit reference to the effects of temporary migration toward the Gulf countries, as these are characterized by an extremely conservative perception of the role of women in the society. Specification (1) in Table 6 restricts the sample to stayers and returnees from a Gulf country. The estimates are in line with our baseline results, and the coefficient of migration experience is positive and significant at the 5 percent confidence level once standard errors are obtained through bootstrapping.

Table 2 showed that the total number of children per woman in Egypt was lower than in all the destination countries but Lebanon in the early 1970s. Over time, fertility in several Arab countries declined at a faster pace than in Egypt, ${ }^{54}$ so that six destination countries had a lower number of children than Egypt by the early 2000s. The hypothesis set out by Fargues (2007, 2011a) implies that returnees from destination countries with a higher fertility should, ceteris paribus, increase their number of children. In line with 
this argument, Table 6 drops out of the sample the Egyptian returnees from countries that had, at different points in time from 1980 to 1995, a lower level of fertility than Egypt. For instance, specification (5) excludes returnees from Algeria Kuwait, Lebanon, Libya and Qatar, as these countries had a total number of children per woman that fell short of the corresponding Egyptian figure in 1995. ${ }^{55}$ Table 6 reports the estimates obtained with the 2SRI estimator on four different samples: the generalized residuals are still negative and significant at least at the 5 percent confidence level, and our key variable of interest is still positive and significant at the 1 percent confidence in all specifications but (5). The coefficient of return migration is always higher, though not significantly so, than the one obtained in our benchmark regression in Table 4 in specifications (2)-(5), consistently with the fact that we are dropping from the sample destinations with a lower fertility. ${ }^{56}$ The robustness of our estimates with respect to the restriction of the sample to different sets of destinations is reassuring, as our instrumentation strategy allows us to address the endogeneity of the decision to migrate, but not the one possibly related to the sorting of the Egyptian migrants across Arab countries.

We also tested the robustness of the results in Table 4 with respect to the selection of a different age at which each male individual in the sample is matched with the real price of oil. Our results, which are not reported but are available from the authors upon request, proved to be robust to the choice of either the age of 18 or 19 that, as evidenced in Figure 2 , displayed the highest value of the $\chi^{2}(1)$ test statistics after our preferred instrument. Estimates obtained when selecting the real price of oil at the age of 21 or above as the instrument in the auxiliary regression turned out to be not significant, in line with the sharp fall in the respective $\chi^{2}(1)$ test statistics. 


\section{Concluding remarks}

The analysis presented in this paper shows that the Egyptian married couples where the husband has a past migration experience in another Arab country have a significantly larger number of children than stayers. The estimates, which have proved to be robust to a number of robustness checks, are stronger once we control for the endogeneity of self-selection into migration with the 2SRI estimator. The direction of the bias induced by the endogeneity of the migration experience in the Poisson regression suggests that Egyptian migrants are, on average, endowed with unobservable characteristics that would have led them to have a lower number of children, had they not migrated. The point estimate of the impact of return migration upon the total number of children in returnee households from our preferred specification stands at 1.20. This suggests that Egyptian returnees have a number of children that is closer to the level that prevails at destination than to the Egyptian one, consistently with the hypothesis advanced by Fargues (2007, 2011a) and with the evidence provided by Beine et al. (2012) on aggregate data. This relevant direct effect upon returnees might not be capturing the whole influence of migration to other Arab countries upon population growth in Egypt, as the social interactions of the returnees with the stayers could contribute to a further diffusion of the fertility norms that prevail at destination. The quantification of the indirect effects on stayers using household-level data can constitute the object of future research.

\section{References}

Al Aswany, A. (2011): On the State of Egypt. Cairo: The American University in Cairo Press.

Ali, K. (2002): Planning the Family in Egypt: New Bodies, New Selves. Austin: Texas 


\section{University Press.}

AssaAD, R. (2004): "Why Did Economic Liberalization Lead to Feminization of the Labor Force in Morocco and De-feminization in Egypt?," paper prepared for the Center of Arab Women, Training and Research (CAWTAR), Tunis.

Assaad, R., C. Binzel, and M. Gadallah (2010): "Transitions to employment and marriage among young men in Egypt," Middle East Development Journal, 2(1), 39-88.

BASU, D., And R. Jong (2010): "Son targeting fertility behavior: Some consequences and determinants," Demography, 47(2), 521-536.

Batista, C., And P. C. Vicente (2011): "Do Migrants Improve Governance at Home? Evidence from a Voting Experiment," World Bank Economic Review, 25(1), 77-104.

Beine, M., F. Docquier, And M. Schiff (2012): "International Migration, Transfers of Norms and Home Country Fertility," Canadian Journal of Economics, forthcoming.

Beine, M., And K. Sekkat (2012): "Skilled Migration and the Transfer of Institutional Norms," ERF Working Paper No. 681, Cairo.

Binzel, C., And R. AssaAd (2011): "Egyptian men working abroad: Labour supply responses by the women left behind," Labour Economics, 18(S1), S98-S114.

Boоth, A., And H. KeE (2009): "Intergenerational transmission of fertility patterns," Oxford Bulletin of Economics and Statistics, 71(2), 183-208.

Cameron, A. C., And P. K. Trivedi (1990): "Regression-based tests for overdispersion in the Poisson model," Journal of Econometrics, 46(3), 347-364.

Cameron, A. C., And P. K. Trivedi (2010): Microeconometrics Using Stata. College Station: Stata Press, revised edition. 
Chen, H.-J. (2006): "International migration and economic growth: a source country perspective," Journal of Population Economics, 19(4), 725-748.

Clingingsmith, D., A. I. Khwaja, and M. Kremer (2009): "Estimating the Impact of The Hajj: Religion and Tolerance in Islam's Global Gathering," Quarterly Journal of Economics, 124(3), 1133-1170.

Cochrane, S. H., M. A. Khan, and I. K. T. Osheba (1990): "Education, Income, and Desired Fertility in Egypt: A Revised Perspective," Economic Development and Cultural Change, 38(2), 313-339.

DAVIS, J. (2011): "Decoupling Migration Effects from Income Effects on Reproduction in Central American Migrant-Sending Households," International Migration Review, 45(2), 325-347.

Docquier, F., E. Lodigiani, H. Rapoport, and M. Schiff (2011): "Emigration and democracy," CReAM Discussion Paper Series No. 02/11, University College London.

EAsterlin, R. A. (1961): "Influences in European Overseas Emigration before World War I," Economic Development and Cultural Change, 9(3), 331-351.

Easterlin, R. A. (1975): "An Economic Framework for Fertility Analysis," Studies in Family Planning, 6(3), 54-63.

El-Zanaty, F., And A. WAy (2009): Egypt Demographic and Health Survey 2008. Cairo: Ministry of Health, El-Zanaty and Associates, and Macro International.

Fang, H., K. N. Eggleston, J. A. Rizzo, and R. J. Zeckhauser (2010): "Female Employment and Fertility in Rural China," NBER Working Paper No. 15886, Cambridge MA. 
Fargues, P. (2007): "The Demographic Benefit of International Migration: Hypothesis and Application to Middle Eastern and North African Contexts," in International Migration, Economic Development and Policy, ed. by Ç. Özden, and M. Schiff, pp. 161-182. Washington: The World Bank.

Fargues, P. (2011a): "International Migration and the Demographic Transition: A TwoWay Interaction," International Migration Review, 45(3), 588-614.

FArGues, P. (2011b): "Croissance et mutations démographiques au ventieme siécle," in L'Egypte au présent, ed. by V. Battesti, and F. Ireton, pp. 41-74. Paris: Actes Sud.

Filmer, D., And L. Pritchett (2001): "Estimating Wealth Effects Without Expenditure Data-Or Tears: An Application To Educational Enrollments In States Of India," Demography, 38, 115-132.

Gardner, A. M. (2011): "Gulf Migration and the Family," Journal of Arabian Studies, $1(1), 3-25$.

Goldscheider, C. (1971): Population, Modernization and Social Structure. Boston: Little, Brown and Company.

Gourieroux, C., A. Monfort, E. Renault, and A. Trognon (1987): "Generalized Residuals," Journal of Econometrics, 34(1-2), 5-32.

Gourieroux, C., A. Monfort, and A. Trognon (1984): "Pseudo Maximum Likelihood Methods: Applications to Poisson Models," Econometrica, 52(3), 701-720.

Hanson, G. H., and C. McIntosh (2010): "The Great Mexican Emigration," The Review of Economics and Statistics, 92(4), 798-810. 
Hanson, G. H., and C. McIntosh (2012): "Birth Rates and Border Crossings: Latin American Migration to the US, Canada, Spain, and the UK," The Economic Journal, 122(561), 707-726.

Hatton, T. J., and J. Williamson (1998): The Age of Mass Migration: Causes and Economic Impact. New York: Oxford University Press.

Hoodfar, H. (1999): Between marriage and the market. Intimate Politics and Survival in Cairo. Cairo: American University in Cairo Press.

Jones, G. (2006): "A demographic perspective on the Muslim world," Journal of Population Research, 23(2), 243-265.

LeHreR, E. (1996): "Religion as a determinant of marital fertility," Journal of Population Economics, 9(2), 173-196.

Lindstrom, D. P., and S. Giorguli Saucedo (2002): "The Short- and Long-Term Effects of U.S. Migration Experience on Mexican Women's Fertility," Social Forces, 80(4), $1341-1368$.

Lindstrom, D. P., And E. Muñoz-Franco (2005): "Migration and the Diffusion of Modern Contraceptive Knowledge and Use in Rural Guatemala," Studies in Family Planning, 36(4), 277-288.

Lodigiani, E., And S. Salomone (2012): "Migration-induced Transfers of Norms. The case of Female Political Empowerment," IRES Discussion Papers No. 2012-1, Université Catholique de Louvain.

LuCAS, R. (2008): International Migration and Economic Development: Lessons from Low Income Countries, US and UK. London: Edward Elgar. 
Marchetta, F. (2012): "Migration and the Survival of Entrepreneurial Activities in Egypt," World Development, 40(10), 1999-2013.

Marchiori, L., P. Pieretti, and B. Zhou (2010): "Migration and Human Capital in an Endogenous Fertility Model," Annals of Economics and Statistics, 97/98, 187-205.

McCormick, B., and J. Wahba (2001): "Overseas work experience, savings and entrepreneurship amongst returnees to LDCs," Scottish Journal of Political Economy, 48(2), $164-178$.

McKenzie, D. (2007): "Paper Walls Are Easier to Tear Down: Passport Costs and Legal Barriers to Emigration," World Development, 35(11), 2026-2039.

McKenzie, D., C. Theoharides, and D. Yang (2013): "Distortions in the International Migrant Labor Market: Evidence from Filipino Migration and Wage Responses to Destination Country Economic Shocks," American Economic Journal: Applied Economics, forthcoming.

McQulllan, K. (2004): "When Does Religion Influence Fertility?," Population and Development Review, 30(1), 25-56.

Mountford, A., And H. RAPoport (2011): "The brain drain and the world distribution of income," Journal of Development Economics, 95(1), 4-17.

Nugent, J. B. (1985): "The Old-Age Security Motive for Fertility," Population and Development Review, 11(1), 75-97.

Omran, A. R. (1992): Family Planning in the Legacy of Islam. London: Routledge.

Özden, Ç., C. R. Parsons, M. Schiff, and T. L. Walmsley (2011): "Where on Earth is Everybody? The Evolution of Global Bilateral Migration 1960-2000," World Bank Economic Review, 25(1), 12-56. 
Piracha, M., And F. VAdean (2010): "Return Migration and Occupational Choice: Evidence from Albania," World Development, 38(8), 1141-1155.

RAsul, I. (2008): "Household bargaining over fertility: Theory and evidence from Malaysia," Journal of Development Economics, 86(2), 215-241.

RAY, D. (1998): Development Economics. Princeton: Princeton University Press.

Richards, A. (1994): "The Egyptian farm labor market revisited," Journal of Development Economics, 43(2), 239-261.

Ross, M. L. (2008): "Oil, Islam, and Women," American Political Science Review, 102, $107-123$.

Singerman, D. (1995): Avenues of Participation: Family, Politics, and Networks in Urban Quarters of Cairo. Princeton: Princeton University Press.

Singerman, D., And B. Ibrahim (2003): "The cost of marriage in Egypt: a hidden variable in the new Arab demography," in The New Arab Family, ed. by N. Hopkins, pp. 80-116. Cairo: American University in Cairo Press.

Spilimbergo, A. (2009): "Democracy and Foreign Education," American Economic Review, 99(1), 528-543.

Terza, J., A. BAsu, and P. Rathouz (2008): "A two stage residual inclusion estimation: addressing endogeneity in health econometric modeling," Journal of Health Economics, $27(3), 531-543$.

WahbA, J. (2007): "Returns to Overseas Work Experience: The Case of Egypt," in International Migration, Economic Development and Policy, ed. by C. Özden, and M. Schiff, pp. 235-258. Washington: The World Bank. 
Wahba, J., And Y. Zenou (2012): "Out of Sight, Out of Mind: Migration, Entrepreneurship and Social Capital," Regional Science and Urban Economics, 42(5), 890-903.

World BAnK (2009): Shaping the Future: A Long-Term Perspective of People and Job Mobility for the Middle East and North Africa. Washinghton: The World Bank.

World BANK (2011): World Development Indicators. Washington: The World Bank.

YAmAGUCHI, K. (1989): "A formal theory for male-preferring stopping rules of childbearing: sex differences in birth order and in the number of siblings," Demography, 26(3), 451-465. 


\section{Notes}

${ }^{1}$ Lindstrom and Giorguli Saucedo (2002), Lindstrom and Muñoz-Franco (2005) and Davis (2011) rely on household-level data to analyze how temporary migration episodes, which are treated as exogenous, influence fertility at origin.

${ }^{2}$ Easterlin (1961) represents an early contribution on the demographic determinants of international migration; see Hanson and McIntosh $(2010,2012)$ for recent econometric evidence for Latin American countries, and Hatton and Williamson (1998) for an account of their role during the age of mass migration at the turn of the twentieth century.

3 "Emigration to the Gulf might be expected to obstruct forces of demographic transition in origin countries." (Fargues, 2011a, p. 597).

${ }^{4}$ Lucas (2008) reports that the average duration of the migration experiences in the countries of the Gulf is around four to five years.

5 "[M]edia attention is also likely to focus on the situation of return migrants, including their modes of behavior, and the extent to which they differ from those of non-migrant." (Beine et al., 2012).

6 "While international migrants of earlier times started to build a family before migrating, new migrants typically leave no spouses or children in the home country" (Fargues, 2011a, p. 592).

${ }^{7}$ The Grand Mufti recently approved the use of abortion during the first four months of pregnancy (Jones, 2006).

${ }^{8}$ Some of the other channels evidenced by Beine et al. (2012) through which migration can influence fertility at origin could be also playing a role here; specifically, Egyptian would-be migrants could be in contact with other migrants before leaving the country, or they could draw on local media to be remain informed about their countries of destination upon return.

${ }^{9}$ See the results of the anthropological research conducted by Singerman (1995), Hoodfar (1999), Singerman and Ibrahim (2003) which show "how deeply models imported from the Gulf by migrants could transform local practices of marriage and family building in their communities of origin" (Fargues, 2011a, p. 597).

${ }^{10}$ The targeting of men by family planning programs in Egypt (Ali, 2002) is actually supportive of a significant male influence in determining the fertility decisions of a couple.

${ }^{11}$ The adoption of a male-preferring stopping rule also implies that girls $(i)$ have a larger number of siblings than boys and (ii) they are born at earlier parities (Yamaguchi, 1989; Basu and Jong, 2010); Section 4 provides evidence about these two effects using the ELMPS 2006 data. 
${ }^{12}$ Similar effects can be produced by the wage premium that Egyptian migrants enjoy upon return (Wahba, 2007).

${ }^{13}$ Section 5.2 provides evidence on the correlation between the past migration experience of the husband and the labor market participation of the wife; see also the estimates by Binzel and Assaad (2011) on the relationship between current male migration and female labor supply.

${ }^{14}$ We follow here the literature on marital childbearing, that regards the formation of couples as given; see, for instance, Easterlin (1975), Cochrane et al. (1990) and Rasul (2008).

${ }^{15}$ Notice that the generalized residuals for a probit model are given by the product between the probability density function $\phi($.$) and the standardized residuals.$

${ }^{16}$ Fang et al. (2010) estimate a Poisson model with the 2SRI estimator to analyze the determinants of fertility in rural China.

${ }^{17}$ The ELMPS 2006 provides information on 6,661 ever-married women, including 6,215 women who are currently married, 264 widows, 129 divorced women and 53 women who signed the Islamic marriage contract but had not yet celebrated the wedding at the time of the survey.

${ }^{18}$ The ELMPS 2006 includes only 25 returnees from non-Arab countries; this low figure is consistent with the predominantly permanent character of Egyptian migration toward these countries, and it does not allow us to estimate the influence of these migration experiences upon the fertility choices of the returnees.

${ }^{19} 334$ out of 394 returnees report to have been working abroad, while 60 returnees are identified as such because they report to have resided abroad; recall that the survey records only the previous two jobs, so that even this second group might have unrecorded work experiences abroad.

${ }^{20}$ This is most likely to occur if returnees have been engaged in repeated migration episodes.

${ }^{21}$ The corresponding figure for 1990 stands at 80.3 percent, up from 71.4 percent in 1980 and 51.8 percent in 1970 .

${ }^{22}$ The different speed of the demographic transition in the various Arab countries of destination will be used to perform some robustness checks on our estimates.

${ }^{23} 247$ out of the 316 couples of returnees with children had their first child after the beginning of the migration experience of the husband, proxied by the year of the first job held abroad that is recorded in the ELMPS 2006.

${ }^{24}$ Neither of the two effects is actually stronger for returnees, consistently with the hypothesis that migration could induce both a stronger preference for sons and a larger desired family size, as a positive correlation between the two blurs the sibling and the birth order effect (Basu and Jong, 2010). 
${ }^{25}$ The influence of such a difference on marital fertility is partly offset by a difference in the timing of childbearing for the couples of returnees and stayers; focusing on the sample of 1,414 women aged 40 and above, which have presumably completed their fertility cycles, we observe that the average age at childbearing is 0.9 years higher for the wives of the returnees. Section 5.3 presents evidence that the difference in the duration of the wedding between stayers and returnees does not influence our estimates of the effect of return migration.

${ }^{26}$ The variables used in the construction of the asset index are: ownership of the dwelling; number of rooms per household member; surface (in squared meters) per household member; material of the walls, floor and roofs; source of water; method of waste disposal; availability of a telephone line; type of sanitation facilities; connection to the electricity network; ownership of a fridge, freezer, air conditioning, motorcycle, car, computer, mobile phone and satellite dish.

${ }^{27}$ See Section 5.1 below for the justification of focusing on the real price of oil measured at the age of 20 .

${ }^{28}$ Figure 1 is built upon 5,472 out of 5,732 Egyptian males in our sample for which we have information on the real price of oil at all ages between 18 and 28.

${ }^{29}$ This set includes the year of migration, which is not reported for returnees, while we do not have information on the age or on the marital status of the absent members, so that we cannot include them in Figure 1.

${ }^{30}$ The index gives us a measure of the "long-run economic status" (Filmer and Pritchett, 2001, p. 116) of the household that is better suited than current wages to control for the impact of economic conditions on cumulative fertility and that does not require to impose any further restriction on our sample.

${ }^{31}$ Booth and Kee (2009) provide evidence of the intergenerational transmission of fertility patterns.

${ }^{32}$ Notice that controlling for the age at the time of the wedding and for the duration of the wedding is more general than just controlling for the age of the wife.

${ }^{33}$ The survey contains the complete fertility history of the mothers aged less than 50 years old that belong to the same household as their married daughters; when this is not the case, we relied on the information on the number of (alive or dead) brothers and sisters of the wife, which we use to build a proxy for the unreported number of children of the mother.

${ }^{34}$ Cochrane et al. (1990) provide evidence on the significant effect of the education of the husband on fertility in Egypt, arguing that "a major channel through which husband's education affects fertility is contraceptive knowledge." (p. 335).

${ }^{35}$ Arab countries have extensively relied on the kafala, or sponsorship, system to regulate the inflow of 
temporary immigrants, which could obtain an entry visa only through a local sponsor (Gardner, 2011).

${ }^{36}$ Richards (1994) refers to surveys conducted by the CAPMAS in the 1980s that evidenced that nearly 80 percent of Egyptian migrants from rural areas stayed abroad less than three years.

${ }^{37}$ McKenzie et al. (2013) provide evidence of the responsiveness of Filipino migration to macroeconomic conditions at destination using these data.

${ }^{38}$ The estimates were conducted on the subsample for which $x_{2 i s}$ is non-missing for all $s=18, \ldots, 28$. The choice of the instrument is unaffected if we let the sample vary across specifications.

${ }^{39}$ Their results are robust to the choice of any age between 25 and 28 years; Marchetta (2012) opts for the price of oil at the age of 21 and she also provides evidence of the robustness of her results to alternative choices.

${ }^{40}$ The survey does not allow us to identify multiple migration episodes, unless a migrant moves to different countries of destination; Table 1 suggests that approximately one tenth of our sample of returnees moved to more than one country of destination.

${ }^{41}$ Similarly, as discussed in Section 4, returnees might have frequently changed their job while abroad, so that the survey fails to record the date of the first employment held outside Egypt.

${ }^{42}$ Regression-based tests following Cameron and Trivedi (1990) on the null hypothesis that the data are equidispersed lead to a rejection of the null; the standard errors presented in all specifications are robust to the violation of the mean-variance equality that characterizes a Poisson distribution.

${ }^{43}$ This result is consistent with the descriptive evidence on the relationship between fertility and the quintiles of the wealth distribution (El-Zanaty and Way, 2009, p. 49)

${ }^{44}$ The correlation between the two variables stands at 0.55 .

${ }^{45}$ We also included the level of education of the father of the wife, which turned out to be non-significant in all specifications, and it was thus excluded from the vector of regressors.

${ }^{46}$ The null hypothesis that the coefficients of the dummies for the governorates are jointly equal to zero is strongly rejected, as the $\chi^{2}(21)$ test statistic stands at 104.24, suggesting that there are relevant geographical differences with respect to fertility in Egypt; our estimates are also robust to the introduction of district fixed effects.

${ }^{47}$ Results, which are available from the authors upon request, are not affected when we define the migration experience only on the basis of past working experiences abroad.

${ }^{48}$ The estimated coefficient of the real price of oil in this specification stands at 0.007 , with a standard error of 0.001 . 
${ }^{49}$ See the provisions of the National Service Act No. 127 (1980).

${ }^{50}$ McKenzie (2007) provides evidence of the impact of the "paper walls" connected to obtaining a passport on outgoing migration flows.

${ }^{51}$ We optimally selected for each specification the age at which each husband was matched with the corresponding real oil price, as described in Section 5.1.

${ }^{52}$ Wahba and Zenou (2012) argue that "oil prices played an important role in the demand for foreign labor directly in the Gulf States, or indirectly as a replacement workers in non-oil Arab countries such as Jordan and Lebanon." (p. 898).

${ }^{53}$ The mean and median age at childbearing have been measured on the subsample of 1,414 married women aged 40 and above, whose fertility cycles are likely to be uncensored; the exclusion of the women aged below 27 allows us to reduce the difference in the duration of the wedding for returnees and stayers from 3.87 to 1.39 years, and a large part of the residual difference is compensated by the difference in the timing of childbearing between the wives of the stayers and of the returnees.

${ }^{54}$ The increased diversity over time in the level of fertility in the Arab countries of destination is reflected in the increase in the coefficient of variation of the total fertility rates in Table 2, which rose from 0.055 (1970-1974) to 0.200 (1995-2000).

${ }^{55}$ Observe that we exclude all returnees from these countries, even if their migration episodes probably occurred at a time when fertility at destination was higher than in Egypt, as the ELMPS 2006 provides only imprecise information on the timing of their migration episodes.

${ }^{56}$ Ideally, as discussed in Section 5.1, we would have more fully exploited the differences across space and time in the fertility norms that Egyptian migrants entered in contact with, but such a richer approach is hindered by the lack of a credible destination-specific instrument. 
Table 1: Distribution of migration episodes across destination countries

\begin{tabular}{lcc} 
Country & Migration episodes & Share \\
\hline Saudi Arabia & 144 & 33.5 \\
Iraq & 137 & 31.9 \\
Jordan & 55 & 12.8 \\
Libya & 46 & 10.7 \\
Kuwait & 20 & 4.7 \\
United Arab Emirates & 11 & 2.6 \\
Lebanon & 5 & 1.2 \\
Qatar & 4 & 0.9 \\
Yemen & 4 & 0.9 \\
Oman & 2 & 0.5 \\
Algeria & 1 & 0.2 \\
Syria & 1 & 0.2 \\
Total & 430 & 100.0 \\
\hline Notes: Figures based on the distribution of the mi- \\
gration episodes of the 394 male returnees in the sam- \\
ple; sampling weights not used.
\end{tabular}

Source: Authors' elaboration on ELMPS 2006 
Table 2: Total fertility rates in Egypt and in the Arab countries of destination, 1970-1999

\begin{tabular}{|c|c|c|c|c|c|c|}
\hline \multirow[b]{2}{*}{ Country } & \multicolumn{6}{|c|}{ Years } \\
\hline & $\begin{array}{l}1970- \\
1974\end{array}$ & $\begin{array}{c}1975- \\
1979\end{array}$ & $\begin{array}{c}1980- \\
1984\end{array}$ & $\begin{array}{c}1985- \\
1989\end{array}$ & $\begin{array}{c}1990- \\
1994\end{array}$ & $\begin{array}{l}1995- \\
1999\end{array}$ \\
\hline Egypt & 5.77 & 5.50 & 5.25 & 4.81 & 4.04 & 3.52 \\
\hline \multicolumn{7}{|l|}{ Destination countries } \\
\hline Algeria & 7.39 & 7.20 & 6.56 & 5.44 & 4.21 & 3.05 \\
\hline Iraq & 7.23 & 6.83 & 6.42 & 6.15 & 5.84 & 5.45 \\
\hline Jordan & 7.81 & 7.44 & 7.09 & 6.47 & 5.33 & 4.38 \\
\hline Kuwait & 6.95 & 6.06 & 5.10 & 3.53 & 2.42 & 2.67 \\
\hline Lebanon & 4.85 & 4.36 & 3.92 & 3.39 & 3.03 & 2.70 \\
\hline Libya & 7.57 & 7.46 & 7.14 & 5.84 & 4.27 & 3.33 \\
\hline Oman & 7.44 & 8.00 & 8.33 & 7.89 & 6.46 & 4.64 \\
\hline Qatar & 6.78 & 6.21 & 5.49 & 4.64 & 4.01 & 3.41 \\
\hline Saudi Arabia & 7.30 & 7.29 & 7.03 & 6.33 & 5.52 & 4.59 \\
\hline Syria & 7.55 & 7.35 & 6.83 & 5.96 & 4.92 & 4.03 \\
\hline United Arab Emirates & 6.39 & 5.75 & 5.28 & 4.84 & 3.99 & 3.07 \\
\hline Yemen & 7.70 & 8.47 & 9.15 & 9.01 & 8.29 & 7.14 \\
\hline Average & 7.30 & 7.05 & 6.69 & 6.05 & 5.26 & 4.56 \\
\hline
\end{tabular}

Notes: the average has been computed over the countries of destination using the figures in Table 1 as weights.

Source: Authors' elaboration on World Bank (2011). 
Table 3: Descriptive statistics

\begin{tabular}{|c|c|c|c|c|}
\hline & & Whole sample & Stayers & Returnees \\
\hline \multirow[t]{5}{*}{ Couple } & Children & $\begin{array}{c}2.63 \\
(1.94)\end{array}$ & $\begin{array}{c}2.57 \\
(1.94)\end{array}$ & $\begin{array}{c}3.24 \\
(1.88)\end{array}$ \\
\hline & Duration of the wedding & $\begin{array}{l}12.16 \\
(9.00)\end{array}$ & $\begin{array}{l}11.87 \\
(9.02)\end{array}$ & $\begin{array}{l}15.64 \\
(7.96)\end{array}$ \\
\hline & Resident in rural areas & $\begin{array}{c}0.58 \\
(0.49)\end{array}$ & $\begin{array}{c}0.57 \\
(0.49)\end{array}$ & $\begin{array}{c}0.66 \\
(0.47)\end{array}$ \\
\hline & Distance from health clinic (minutes) & $\begin{array}{c}14.30 \\
(10.02)\end{array}$ & $\begin{array}{c}14.35 \\
(10.21)\end{array}$ & $\begin{array}{l}13.61 \\
(7.32)\end{array}$ \\
\hline & Asset index & $\begin{array}{c}37.02 \\
(14.89)\end{array}$ & $\begin{array}{c}36.65 \\
(14.62)\end{array}$ & $\begin{array}{c}41.58 \\
(17.25)\end{array}$ \\
\hline \multirow[t]{7}{*}{ Wife } & Age & $\begin{array}{l}31.83 \\
(8.62)\end{array}$ & $\begin{array}{l}31.51 \\
(8.60)\end{array}$ & $\begin{array}{l}35.86 \\
(7.79)\end{array}$ \\
\hline & Age at the wedding & $\begin{array}{l}19.68 \\
(4.17)\end{array}$ & $\begin{array}{l}19.63 \\
(4.15)\end{array}$ & $\begin{array}{l}20.22 \\
(4.34)\end{array}$ \\
\hline & Years of schooling & $\begin{array}{c}6.67 \\
(6.29)\end{array}$ & $\begin{array}{c}6.67 \\
(6.30)\end{array}$ & $\begin{array}{c}6.71 \\
(6.21)\end{array}$ \\
\hline & Mother, number of children & $\begin{array}{c}6.49 \\
(2.61)\end{array}$ & $\begin{array}{l}6.45 \\
(2.58)\end{array}$ & $\begin{array}{c}6.94 \\
(2.88)\end{array}$ \\
\hline & Mother, illiterate & $\begin{array}{c}0.79 \\
(0.40)\end{array}$ & $\begin{array}{c}0.79 \\
(0.40)\end{array}$ & $\begin{array}{c}0.78 \\
(0.42)\end{array}$ \\
\hline & Mother, primary education & $\begin{array}{c}0.18 \\
(0.38)\end{array}$ & $\begin{array}{c}0.18 \\
(0.38)\end{array}$ & $\begin{array}{c}0.20 \\
(0.40)\end{array}$ \\
\hline & Mother, secondary and above & $\begin{array}{c}0.03 \\
(0.17)\end{array}$ & $\begin{array}{c}0.03 \\
(0.18)\end{array}$ & $\begin{array}{c}0.02 \\
(0.14)\end{array}$ \\
\hline \multirow[t]{5}{*}{ Husband } & Age & $\begin{array}{l}38.69 \\
(9.96)\end{array}$ & $\begin{array}{c}38.26 \\
(10.00)\end{array}$ & $\begin{array}{l}43.94 \\
(7.77)\end{array}$ \\
\hline & Age at the wedding & $\begin{array}{l}26.53 \\
(5.79)\end{array}$ & $\begin{array}{l}26.39 \\
(5.77)\end{array}$ & $\begin{array}{l}28.30 \\
(5.78)\end{array}$ \\
\hline & Years of schooling & $\begin{array}{c}7.26 \\
(6.27)\end{array}$ & $\begin{array}{c}7.30 \\
(6.27)\end{array}$ & $\begin{array}{c}6.80 \\
(6.23)\end{array}$ \\
\hline & Returnee & $\begin{array}{l}0.075 \\
(0.26)\end{array}$ & $\begin{array}{c}0.00 \\
(0.00)\end{array}$ & $\begin{array}{l}1.00 \\
(0.00)\end{array}$ \\
\hline & Real oil price at the age of 20 & $\begin{array}{c}40.19 \\
(20.79)\end{array}$ & $\begin{array}{c}39.41 \\
(20.30)\end{array}$ & $\begin{array}{c}49.84 \\
(24.08)\end{array}$ \\
\hline
\end{tabular}

Notes: Standard deviation in parentheses; sampling weights used; the asset index ranges between 0 and 100.

Source: Authors' elaboration on ELMPS 2006 and www.inflationdata.com 


\section{Table 4: Determinants of total fertility}

Dependent variable: total number of children

\begin{tabular}{|c|c|c|c|c|}
\hline & (1) & (2) & (3) & (4) \\
\hline Returnee & & $\begin{array}{c}0.082^{* * *} \\
(0.025)\end{array}$ & $\begin{array}{c}0.414^{* * *} \\
(0.125)\end{array}$ & $\begin{array}{c}0.414^{* *} \\
(0.165)\end{array}$ \\
\hline Generalized residuals & & & $\begin{array}{c}-0.028^{* * *} \\
(0.010)\end{array}$ & $\begin{array}{c}-0.028^{* *} \\
(0.013)\end{array}$ \\
\hline Duration of the wedding & $\begin{array}{c}0.053^{* * *} \\
(0.001)\end{array}$ & $\begin{array}{c}0.053^{* * *} \\
(0.001)\end{array}$ & $\begin{array}{c}0.052^{\text {*** }} \\
(0.001)\end{array}$ & $\begin{array}{c}0.052^{* * *} \\
(0.001)\end{array}$ \\
\hline Asset index & $\begin{array}{c}-0.002^{* * *} \\
(0.001)\end{array}$ & $\begin{array}{c}-0.002^{* * *} \\
(0.001)\end{array}$ & $\begin{array}{c}-0.003^{* * *} \\
(0.001)\end{array}$ & $\begin{array}{c}-0.003^{* * *} \\
(0.001)\end{array}$ \\
\hline Wife, age at the wedding & $\begin{array}{l}-0.003 \\
(0.002)\end{array}$ & $\begin{array}{l}-0.004 \\
(0.002)\end{array}$ & $\begin{array}{c}-0.005^{* *} \\
(0.002)\end{array}$ & $\begin{array}{c}-0.005^{* *} \\
(0.003)\end{array}$ \\
\hline Wife, years of schooling & $\begin{array}{c}-0.006^{* * *} \\
(0.002)\end{array}$ & $\begin{array}{c}-0.006^{* * *} \\
(0.002)\end{array}$ & $\begin{array}{c}-0.006^{* * *} \\
(0.002)\end{array}$ & $\begin{array}{c}-0.006^{* * *} \\
(0.002)\end{array}$ \\
\hline Husband, years of schooling & $\begin{array}{l}-0.002 \\
(0.002)\end{array}$ & $\begin{array}{l}-0.002 \\
(0.001)\end{array}$ & $\begin{array}{l}-0.001 \\
(0.001)\end{array}$ & $\begin{array}{l}-0.001 \\
(0.002)\end{array}$ \\
\hline Mother, primary education & $\begin{array}{c}0.022 \\
(0.020)\end{array}$ & $\begin{array}{c}0.022 \\
(0.020)\end{array}$ & $\begin{array}{c}0.020 \\
(0.020)\end{array}$ & $\begin{array}{c}0.020 \\
(0.022)\end{array}$ \\
\hline Mother, secondary education & $\begin{array}{c}-0.105^{* *} \\
(0.045)\end{array}$ & $\begin{array}{c}-0.104^{* *} \\
(0.045)\end{array}$ & $\begin{array}{c}-0.098^{* *} \\
(0.045)\end{array}$ & $\begin{array}{c}-0.098^{* *} \\
(0.045)\end{array}$ \\
\hline Mother, number of children & $\begin{array}{c}0.012^{* * *} \\
(0.003)\end{array}$ & $\begin{array}{c}0.011^{* * *} \\
(0.003)\end{array}$ & $\begin{array}{c}0.010^{* * *} \\
(0.003)\end{array}$ & $\begin{array}{c}0.010^{* * *} \\
(0.003)\end{array}$ \\
\hline Distance from health clinic & $\begin{array}{c}0.001^{* *} \\
(0.001)\end{array}$ & $\begin{array}{c}0.001^{* *} \\
(0.001)\end{array}$ & $\begin{array}{c}0.001^{* *} \\
(0.001)\end{array}$ & $\begin{array}{l}0.001^{*} \\
(0.001)\end{array}$ \\
\hline Rural areas & $\begin{array}{c}0.078^{* * *} \\
(0.017)\end{array}$ & $\begin{array}{c}0.074^{* * *} \\
(0.017)\end{array}$ & $\begin{array}{c}0.059^{* * *} \\
(0.018)\end{array}$ & $\begin{array}{c}0.059^{* * *} \\
(0.019)\end{array}$ \\
\hline Governorate dummies & Yes & Yes & Yes & Yes \\
\hline Observations & 5,732 & 5,732 & 5,732 & 5,732 \\
\hline $\operatorname{corr}\left(q_{i}, \widehat{q}_{i}\right)$ & 0.559 & 0.561 & 0.562 & 0.562 \\
\hline $\begin{array}{l}\text { Instrument } \\
\chi^{2}(1)\end{array}$ & & & $\begin{array}{c}20 \\
32.46^{* * *}\end{array}$ & $\begin{array}{c}20 \\
32.46^{* * *}\end{array}$ \\
\hline
\end{tabular}

Notes: Robust standard errors in parentheses; standard errors for specification (4) obtained through bootstrapping, 1,000 replications with replacement; $\operatorname{corr}\left(q_{i}, \widehat{q}_{i}\right)$ is the correlation between the actual and the predicted number of children; instrument reports the age at which each individual is matched to the corresponding real oil price; $\chi^{2}(1)$ test on the null hypothesis that the coefficient of the real oil price in the auxiliary regression is equal to zero; ${ }^{* * *} \mathrm{p}<0.01$, ** $\mathrm{p}<0.05,{ }^{*} \mathrm{p}<0.1$.

Source: Authors' elaboration on ELMPS 2006 and www.inflationdata.com 
Table 5: Determinants of total fertility, robustness checks

Dependent variable: total number of children

Husband above $24 \quad$ OPEC countries $\quad$ Wife above 26

\begin{tabular}{|c|c|c|c|c|c|c|}
\hline & $(1)$ & $(2)$ & $(3)$ & $(4)$ & $(5)$ & $(6)$ \\
\hline \multirow[t]{2}{*}{ Returnee } & $0.075^{* * *}$ & $0.441^{* * *}$ & $0.087^{* * *}$ & $0.417^{* *}$ & $0.062^{* * *}$ & $0.311^{* *}$ \\
\hline & $(0.024)$ & $(0.163)$ & $(0.027)$ & $(0.178)$ & $(0.024)$ & $(0.143)$ \\
\hline \multirow[t]{2}{*}{ Generalized residuals } & & $-0.031^{* *}$ & & $-0.028^{*}$ & & $-0.021^{*}$ \\
\hline & & $(0.013)$ & & $(0.014)$ & & $(0.012)$ \\
\hline \multirow[t]{2}{*}{ Duration of the wedding } & $0.050^{* * *}$ & $0.049^{* * *}$ & $0.052^{* * *}$ & $0.052^{* * *}$ & $0.033^{* * *}$ & $0.033^{* * *}$ \\
\hline & $(0.001)$ & $(0.001)$ & $(0.001)$ & $(0.001)$ & $(0.001)$ & $(0.001)$ \\
\hline \multirow[t]{2}{*}{ Asset index } & $-0.002^{* * *}$ & $-0.003^{* * *}$ & $-0.002^{* * *}$ & $-0.003^{* * *}$ & $-0.002^{* * *}$ & $-0.003^{* * *}$ \\
\hline & $(0.001)$ & $(0.001)$ & $(0.001)$ & $(0.001)$ & $(0.001)$ & $(0.001)$ \\
\hline \multirow[t]{2}{*}{ Wife, age at the wedding } & $-0.007 * * *$ & $-0.009 * * *$ & -0.004 & $-0.005^{* *}$ & $-0.024^{* * *}$ & $-0.025^{* * *}$ \\
\hline & $(0.002)$ & $(0.003)$ & $(0.002)$ & $(0.002)$ & $(0.003)$ & $(0.003)$ \\
\hline \multirow[t]{2}{*}{ Wife, years of schooling } & $-0.007 * * *$ & $-0.007 * * *$ & $-0.006^{* * *}$ & $-0.006^{* * *}$ & $-0.005^{* * *}$ & $-0.006^{* * *}$ \\
\hline & $(0.001)$ & $(0.002)$ & $(0.002)$ & $(0.002)$ & $(0.002)$ & $(0.002)$ \\
\hline \multirow[t]{2}{*}{ Husband, years of schooling } & -0.001 & 0.000 & -0.001 & -0.001 & 0.002 & $0.003^{*}$ \\
\hline & $(0.001)$ & $(0.001)$ & $(0.002)$ & $(0.002)$ & $(0.002)$ & $(0.002)$ \\
\hline \multirow[t]{2}{*}{ Mother, primary education } & 0.017 & 0.015 & 0.022 & 0.020 & 0.013 & 0.012 \\
\hline & $(0.020)$ & $(0.020)$ & $(0.020)$ & $(0.022)$ & $(0.020)$ & $(0.021)$ \\
\hline \multirow[t]{2}{*}{ Mother, secondary education } & $-0.099^{* *}$ & $-0.092^{*}$ & $-0.104^{* *}$ & $-0.099^{* *}$ & -0.062 & -0.056 \\
\hline & $(0.044)$ & $(0.047)$ & $(0.045)$ & $(0.048)$ & $(0.038)$ & $(0.040)$ \\
\hline \multirow[t]{2}{*}{ Mother, number of children } & $0.012^{* * *}$ & $0.010^{* * *}$ & $0.011^{* * *}$ & $0.010^{* * *}$ & $0.011^{* * *}$ & $0.010^{* * *}$ \\
\hline & $(0.003)$ & $(0.003)$ & $(0.003)$ & $(0.003)$ & $(0.003)$ & $(0.003)$ \\
\hline \multirow[t]{2}{*}{ Distance from health clinic } & $0.001^{*}$ & $0.001^{*}$ & $0.001^{* *}$ & $0.001^{*}$ & $0.001^{*}$ & $0.002^{*}$ \\
\hline & $(0.001)$ & $(0.001)$ & $(0.001)$ & $(0.001)$ & $(0.001)$ & $(0.001)$ \\
\hline \multirow[t]{2}{*}{ Rural areas } & $0.074^{* * *}$ & $0.057^{* * *}$ & $0.073^{* * *}$ & $0.059^{* * *}$ & $0.087 * * *$ & $0.077^{* * *}$ \\
\hline & $(0.017)$ & $(0.019)$ & $(0.018)$ & $(0.019)$ & $(0.018)$ & $(0.020)$ \\
\hline Governorate dummies & Yes & Yes & Yes & Yes & Yes & Yes \\
\hline Observations & 5,484 & 5,484 & 5,679 & 5,679 & 3,840 & 3,840 \\
\hline $\operatorname{corr}\left(q_{i}, \widehat{q}_{i}\right)$ & 0.556 & 0.558 & 0.560 & 0.561 & 0.495 & 0.496 \\
\hline Instrument & & 20 & & 19 & & 20 \\
\hline$\chi^{2}(1)$ & & $32.20 * * *$ & & $35.61^{* * *}$ & & $22.14^{* * *}$ \\
\hline
\end{tabular}

Notes: Robust standard errors in parentheses; standard errors for specifications (2), (4) and (6) obtained through bootstrapping, 1,000 replications with replacement; $\operatorname{corr}\left(q_{i}, \widehat{q}_{i}\right)$ is the correlation between the actual and the predicted number of children; instrument reports the age at which each individual is matched to the corresponding real oil price; $\chi^{2}(1)$ test on the null hypothesis that the coefficient of the real oil price in the auxiliary regression is equal to zero; ${ }^{* * *} \mathrm{p}<0.01,{ }^{* *} \mathrm{p}<0.05,{ }^{*} \mathrm{p}<0.1$.

Source: Authors' elaboration on ELMPS 2006 and www.inflationdata.com. 
Table 6: Determinants of total fertility, restrictions on the destination countries

\begin{tabular}{|c|c|c|c|c|c|}
\hline \\
\hline & Gulf & 1980 & 1985 & 1990 & 1995 \\
\hline & $(1)$ & $(2)$ & $(3)$ & $(4)$ & $(5)$ \\
\hline \multirow[t]{2}{*}{ Returnee } & $0.336^{* *}$ & $0.501^{* * *}$ & $0.449^{* * *}$ & $0.444^{* * *}$ & $0.515^{* *}$ \\
\hline & $(0.169)$ & $(0.182)$ & $(0.166)$ & $(0.162)$ & $(0.168)$ \\
\hline \multirow{2}{*}{ Generalized residuals } & -0.021 & $-0.036^{* *}$ & $-0.031^{* *}$ & $-0.030 * *$ & $-0.036^{* * *}$ \\
\hline & $(0.014)$ & $(0.015)$ & $(0.013)$ & $(0.013)$ & $(0.013)$ \\
\hline \multirow[t]{2}{*}{ Duration of the wedding } & $0.052^{* * *}$ & $0.052^{* * *}$ & $0.052^{* * *}$ & $0.052^{* * *}$ & $0.052^{* * *}$ \\
\hline & $(0.001)$ & $(0.001)$ & $(0.001)$ & $(0.001)$ & $(0.001)$ \\
\hline \multirow[t]{2}{*}{ Asset index } & $-0.003^{* * *}$ & $-0.003^{* * *}$ & $-0.003^{* * *}$ & $-0.003^{* * *}$ & $-0.003^{* * *}$ \\
\hline & $(0.001)$ & $(0.001)$ & $(0.001)$ & $(0.001)$ & $(0.001)$ \\
\hline \multirow[t]{2}{*}{ Wife, age at the wedding } & $-0.005^{*}$ & $-0.006^{* *}$ & $-0.006^{* *}$ & $-0.006^{* *}$ & $-0.006^{* *}$ \\
\hline & $(0.003)$ & $(0.003)$ & $(0.003)$ & $(0.003)$ & $(0.003)$ \\
\hline \multirow[t]{2}{*}{ Wife, years of schooling } & $-0.006^{* * *}$ & $-0.006^{* * *}$ & $-0.006^{* * *}$ & $-0.006^{* * *}$ & $-0.006^{* * *}$ \\
\hline & $(0.002)$ & $(0.002)$ & $(0.002)$ & $(0.002)$ & $(0.002)$ \\
\hline \multirow[t]{2}{*}{ Husband, years of schooling } & -0.001 & -0.001 & -0.001 & -0.001 & -0.001 \\
\hline & $(0.002)$ & $(0.002)$ & $(0.002)$ & $(0.002)$ & $(0.002)$ \\
\hline \multirow{2}{*}{ Mother, primary education } & 0.022 & 0.020 & 0.022 & 0.022 & 0.018 \\
\hline & $(0.020)$ & $(0.020)$ & $(0.021)$ & $(0.020)$ & $(0.021)$ \\
\hline \multirow[t]{2}{*}{ Mother, secondary education } & $-0.103^{* *}$ & $-0.096^{* *}$ & $-0.100^{* *}$ & $-0.101^{* *}$ & $-0.109^{* *}$ \\
\hline & $(0.045)$ & $(0.046)$ & $(0.047)$ & $(0.047)$ & $(0.048)$ \\
\hline \multirow[t]{2}{*}{ Mother, number of children } & $0.010^{* * *}$ & $0.010^{* * *}$ & $0.010^{* * *}$ & $0.010^{* * *}$ & $0.010^{* * *}$ \\
\hline & $(0.003)$ & $(0.003)$ & $(0.003)$ & $(0.003)$ & $(0.003)$ \\
\hline \multirow[t]{2}{*}{ Distance from health clinic } & $0.001^{* *}$ & $0.001^{* *}$ & $0.001^{*}$ & $0.001^{*}$ & $0.001^{*}$ \\
\hline & $(0.001)$ & $(0.001)$ & $(0.001)$ & $(0.001)$ & $(0.001)$ \\
\hline \multirow[t]{2}{*}{ Rural areas } & $0.066^{* * *}$ & $0.055^{* * *}$ & $0.058 * * *$ & $0.059 * * *$ & $0.062^{* * *}$ \\
\hline & $(0.018)$ & $(0.019)$ & $(0.019)$ & $(0.019)$ & $(0.018)$ \\
\hline Governorate dummies & Yes & Yes & Yes & Yes & Yes \\
\hline Observations & 5,644 & 5,731 & 5,708 & 5,707 & 5,671 \\
\hline $\operatorname{corr}\left(q_{i}, \widehat{q}_{i}\right)$ & 0.561 & 0.563 & 0.562 & 0.562 & 0.562 \\
\hline Instrument & 19 & 19 & 20 & 20 & 19 \\
\hline$\chi^{2}(1)$ & $45.77^{* * *}$ & $31.96^{* * *}$ & $35.30^{* * *}$ & $35.85 * * *$ & $43.08^{* * *}$ \\
\hline
\end{tabular}

Notes: Robust standard errors in parentheses, obtained through bootstrapping, 1,000 replications with replacement; $\operatorname{corr}\left(q_{i}, \widehat{q}_{i}\right)$ is the correlation between the actual and the predicted number of children; instrument reports the age at which each individual is matched to the corresponding real oil price; $\chi^{2}(1)$ test on the null hypothesis that the coefficient of the real oil price in the auxiliary regression is equal to zero; (2) excludes returnees from Lebanon; (3) excludes returnees from Kuwait, Lebanon and Qatar; (4) excludes returnees from Algeria, Kuwait, Lebanon and Qatar; (5) excludes returnees from Algeria Kuwait, Lebanon, Libya and Qatar; *** $\mathrm{p}<0.01,{ }^{* *} \mathrm{p}<0.05,{ }^{*} \mathrm{p}<0.1$.

Source: Authors' elaboration on ELMPS 2006 and www.inflationdata.com 
Figure 1: Share of returnees by year of birth and real oil price at the age of 20

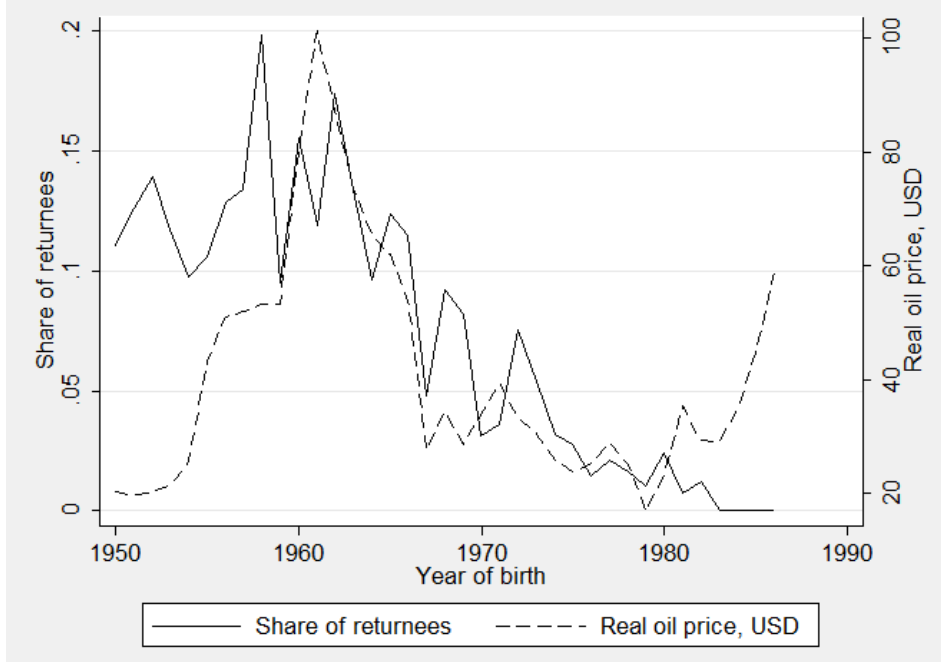

Source: Authors' elaboration on ELMPS 2006 and www.inflationdata.com

Figure 2: First stage, $\chi^{2}(1)$ test statistics for the real oil price at different ages

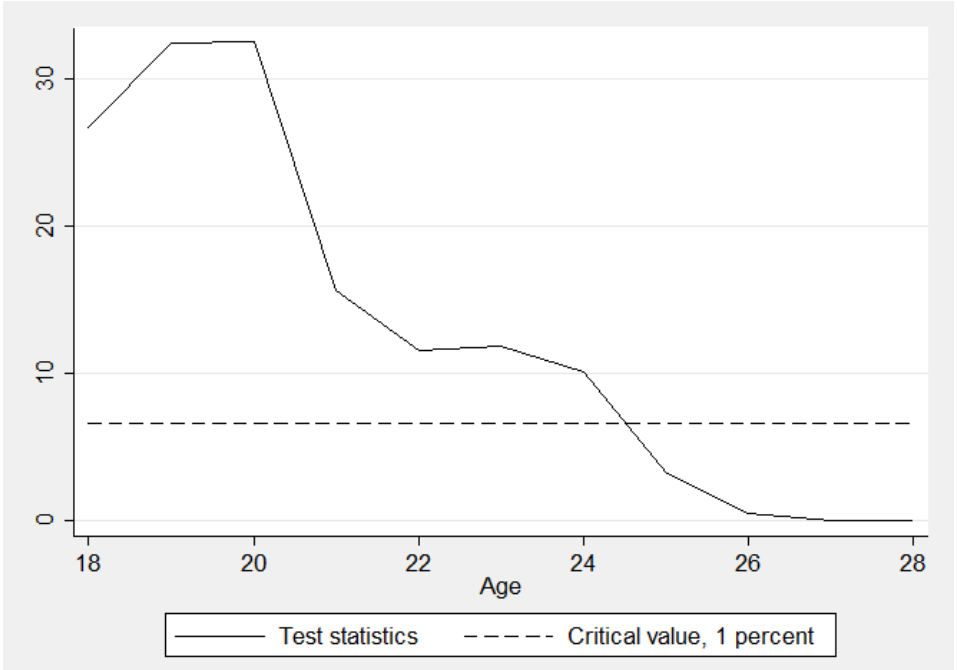

Source: Authors' elaboration on ELMPS 2006 and www.inflationdata.com 